\title{
Yapese Language
}

National Cancer Institute

\section{Source}

National Cancer Institute. Yapese Language. NCI Thesaurus. Code C154202.

An Austronesian language spoken by the people on the island of Yap, Federated States of Micronesia. 